\title{
Simultaneous purification of nitrile hydratase and amidase of Alcaligenes sp. MTCC 10674
}

\author{
S. K. Bhatia $\cdot$ P. K. Mehta $\cdot$ R. K. Bhatia $\cdot$ \\ T. C. Bhalla
}

Received: 13 July 2013/ Accepted: 12 August 2013/Published online: 27 August 2013

(c) The Author(s) 2013. This article is published with open access at Springerlink.com

\begin{abstract}
Alcaligenes sp. MTCC 10674 has a bienzymatic system for the hydrolysis of nitriles. The nitrile hydratase and amidase have been purified simultaneously to homogeneity using a combination of $(\mathrm{NH})_{4} \mathrm{SO}_{4}$ precipitation, ion exchange chromatography and gel permeation chromatography. Nitrile hydratase and amidase have molecular weight of 47 and $114 \mathrm{kDa}$, respectively and exist as heterodimer. Optimum temperatures for maximum activity of nitrile hydratase and amidase were $15{ }^{\circ} \mathrm{C}$ (2.4 $\mathrm{U} / \mathrm{mg}$ protein) and $45^{\circ} \mathrm{C}(2.3 \mathrm{U} / \mathrm{mg}$ protein), respectively. Nitrile hydratase showed maximum $7.8 \mathrm{U} / \mathrm{mg}$ protein at $50 \mathrm{mM}$ acrylonitrile and amidase has $9.2 \mathrm{U} / \mathrm{mg}$ protein at $25 \mathrm{mM}$ propionamide. Nitrile hydratase has $V_{\max }$ $10 \mu \mathrm{mol} / \mathrm{min} / \mathrm{mg}$ and $K_{\mathrm{m}} 40 \mathrm{mM}$, while amidase has $V_{\max }$ $12.5 \mu \mathrm{mol} / \mathrm{min} / \mathrm{mg}$ and $K_{\mathrm{m}} 45.5 \mathrm{mM}$, respectively. Heavy metal ions $\mathrm{Hg}^{2+}, \mathrm{Ag}^{+}, \mathrm{Pb}^{2+}$ and $\mathrm{Cu}^{2+}$ were strong inhibitors of nitrile hydratase and amidase activity.
\end{abstract}

Keywords Alcaligenes sp. MTCC 10674 - Bienzymatic · Nitrile hydratase $\cdot$ Amidase

\section{Introduction}

Nitrilase (EC 3.5.5.1), nitrile hydratase (EC 4.2.1.84) and amidase (EC 3.5.1.4) constitute an important class of nitrilase superfamily (Branner 2002). Nitrilase hydrolyzes the nitriles to acids and ammonia in one-step reaction (Sorokin et al. 2007). However, nitrile hydratase first hydrates the nitrile to corresponding amide which is

S. K. Bhatia · P. K. Mehta · R. K. Bhatia · T. C. Bhalla $(\bowtie)$ Department of Biotechnology, Himachal Pradesh University, Summer Hill, Shimla 171005, India

e-mail: bhallatc@rediffmail.com subsequently hydrolyzed by amidases into organic acid and ammonia (Bhalla and Kumar 2005; Bhatia et al. 2013). There is considerable industrial interest in the enzymatic conversion of nitriles because of the increasing demand for conducting such conversions under mild conditions that are often compatible with the sensitive structures of many industrially important compounds. This environmental friendly bioconversion allows clean and mild synthesis with high selectivity and yield. Several bioprocesses have already been reported for the conversion of nitriles and amide compounds into their corresponding acids (Raj et al. 2006). Number of amides has been synthesized using nitrile hydratase, e.g., nicotinamide and butyramide (Raj et al. 2006; Prasad et al. 2007). Amidases are used as catalyst in effluent treatment and their acyltransferase activity is harnessed for the synthesis of pharmaceutically important compounds such as acetohydroxamic acids and benzohydroxamic acid (Prasad et al. 2007; Sharma et al. 2012; Bhatia et al. 2012). Despite immense potential of these hydrolyzing enzymes, these are not used for the commercial production of acids because of non availability of desired enzymes vis-à-vis their cost, selectivity and stability. Alcaligenes sp. MTCC 10674 has a nitrile hydratase and amidase bienzymatic system for the hydrolysis of nitriles. Nitrile hydratase and amidase system was used for the production of $\alpha$-hydroxyisobutyric acid from $\alpha$-hydroxyisobutyronitrile (Bhatia et al. 2013), which finds its use in the synthesis of polymethyl methacrylate and acrylic glass (Singh et al. 2006) and acyltransferase activity of amidase used for benzohydroxamic acid production (Bhatia et al. 2012). Whole cell has nitrile hydratase activity accompanied with amidase activity which led to carboxylic acid as side product during the conversion of nitriles into amide (Brady et al. 2004), and purified enzyme can be used to overcome this. Therefore, the objective of 
present study was to develop simple steps for the purification of nitrile hydratase and amidase to reduce the cost of enzyme production and to characterize the nitrile hydratase and amidase using acrylonitrile and propionamide as substrate, respectively.

\section{Materials and methods}

\section{Chemicals}

All chemicals were of analytical grade and they were purchased from Alfa Aesar, Johnson Matthey Company and Sigma (India).

Medium and cultural conditions

Alcaligenes sp. MTCC 10674 previously isolated from the soil sample of orchid garden of Kinnaur District of Himachal Pradesh (India), was cultured in minimal salt media (MSM) having $\mathrm{pH} 7.0$ and containing $\mathrm{g} / \mathrm{L}, \mathrm{Na}_{2} \mathrm{H}$ $\mathrm{PO}_{4} \cdot 12 \mathrm{H}_{2} \mathrm{O} 2.5 \mathrm{~g}, \mathrm{~K}_{2} \mathrm{HPO}_{4} 2.0 \mathrm{~g}, \mathrm{MgSO}_{4} \cdot 7 \mathrm{H}_{2} \mathrm{O} 1.0 \mathrm{~g}$, $\mathrm{FeSO}_{4} \cdot 7 \mathrm{H}_{2} \mathrm{O} 0.1 \mathrm{~g}, \mathrm{CaCl}_{2} \cdot 2 \mathrm{H}_{2} \mathrm{O} 0.6 \mathrm{~g}$, peptone $5.0 \mathrm{~g}$ at temperature $25{ }^{\circ} \mathrm{C}$ for $24 \mathrm{~h}$. MSM was supplemented with $40 \mathrm{mM}$ isobutyronitrile after $6 \mathrm{~h}$ of growth as nitrogen source.

Enzyme assay of nitrile hydratase and amidase

\section{Nitrile hydratase assay}

The assay mixture contained $0.125 \mathrm{M} \mathrm{NaH} \mathrm{PO}_{4} / \mathrm{Na}_{2} \mathrm{HPO}_{4}$ buffer ( $\mathrm{pH} 8.0), 50 \mathrm{mM}$ acrylonitrile and purified nitrile hydratase of Alcaligenes sp. MTCC 10674 at $15{ }^{\circ} \mathrm{C}$ for $20 \mathrm{~min}$. Acrylamide production was measured spectrophotometrically at $230 \mathrm{~nm}$. One unit of nitrile hydratase activity was defined as amount of enzyme that hydrates the acrylonitrile to release $1 \mu \mathrm{mol}$ of acrylamide per minute under assay condition.

\section{Amidase assay}

Assay of purified amidase was carried out in $0.075 \mathrm{M}$ $\mathrm{NaH}_{2} \mathrm{PO}_{4} / \mathrm{Na}_{2} \mathrm{HPO}_{4}$ buffer (8.0), $50 \mathrm{mM}$ amide and purified amidase of Alcaligenes sp. MTCC 10674 at $45^{\circ} \mathrm{C}$ for $20 \mathrm{~min}$. Ammonia assay was performed for the amidase activity. One unit of amidase activity was defined as the amount of enzyme that hydrolyzes the propionamide to release $1 \mu \mathrm{mol}$ of ammonia per minute under assay condition. Protein estimation was done according to Bradford method (Bradford 1976).
Purification of nitrile hydratase and amidase

\section{Preparation of cell free extract}

Alcaligenes sp. MTCC 10674 cells were cultured in $1 \mathrm{~L}$ minimal salt medium at $25{ }^{\circ} \mathrm{C}$. After $24 \mathrm{~h}$ of incubation, cells were harvested from the culture broth by centrifugation at $10,000 \mathrm{~g}$ and washed twice with $0.1 \mathrm{M} \mathrm{K}_{2} \mathrm{HPO}_{4} /$ $\mathrm{KH}_{2} \mathrm{PO}_{4}$ (pH 7.0) and suspended in the same buffer. Bacterial culture of Alcaligenes sp. MTCC 10674 (15 mg/ $\mathrm{ml}$ ) was disrupted using BeadBeater ${ }^{\mathrm{TM}}$. The resultant suspension was centrifuged at $10,000 \mathrm{~g}$ at $4{ }^{\circ} \mathrm{C}$ for $20 \mathrm{~min}$ to remove cell debris. The supernatant fluid was designated as the cell free extract (cell lysate) and stored at $4{ }^{\circ} \mathrm{C}$.

\section{Ammonium sulfate fractionation}

The cell free extract was subjected to ammonium sulfate saturation (20-60\%) and the precipitates collected after centrifugation at $15,000 \mathrm{~g}\left(25 \mathrm{~min}\right.$ at $\left.4{ }^{\circ} \mathrm{C}\right)$ were suspended and dialyzed against the same buffer. The ammonium sulfate fractionate (ASF) having nitrile hydratase and amidase activity was further used for purification.

\section{Ion exchange chromatography}

The ASF having nitrile hydratase and amidase activity were subjected to DEAE-ion exchange chromatography. After loading the ASF onto the column, it was washed with potassium phosphate buffer $\mathrm{pH} 7.0(0.05 \mathrm{M})$, until there was no further elution of protein. The column was subsequently eluted with a linear gradient of $\mathrm{NaCl}$ (from 0 to $0.5 \mathrm{M})$ in the same buffer.

\section{Gel permeation chromatography}

The protein fraction of ion exchange chromatography having amidase activity were pooled together and applied to gel permeation chromatography column. The gel permeation chromatography was performed using column $(2.6 \times 60 \mathrm{~cm})$ packed with Sephacryl S-100 high resolution (GE Healthcare) matrix. The gel permeation column was pre-equilibrated with buffer and it was eluted with potassium phosphate buffer $\mathrm{pH} 7.0(0.05 \mathrm{M})$ at a flow rate of $1.0 \mathrm{ml} / \mathrm{min}$. The molecular weights of purified nitrile hydratase/amidase of Alcaligenes sp. MTCC 10674 were determined by SDS/Native-PAGE (Laemmli 1970). 
Characterization of purified nitrile hydratase/amidase

\section{Buffer $p H$}

The activities of purified nitrile hydrolyzing enzymes of Alcaligenes sp. MTCC 10674 were assayed in different buffers, e.g., citrate buffer (4.0-6.0), sodium phosphate buffer (6.0-8.0), potassium phosphate buffer (6.0-8.0), borate buffer (7.0-9.0) and carbonate buffer (9.0-10.0). The $1.0 \mathrm{ml}$ reaction mixture contained $0.1 \mathrm{M}$ of specified buffer, and different substrates, acrylonitrile for nitrile hydratase and propionamide for amidase. Reaction was carried out at $30^{\circ} \mathrm{C}$ for $1 \mathrm{~h}$.

\section{Buffer molarity and temperature}

The activity of purified nitrile hydrolyzing enzyme was estimated in $\mathrm{K}_{2} \mathrm{HPO}_{4} / \mathrm{KH}_{2} \mathrm{PO}_{4}$. The effect of buffer molarity on the activities of the enzymes was studied by varying the buffer concentration from 0.025 to $0.125 \mathrm{M}$ in the reaction. The temperature optimum was determined by varying reaction temperature from 25 to $55^{\circ} \mathrm{C}$.

\section{Incubation time and stability}

Incubation time for optimum activity of nitrile hydrolyzing enzyme was studied by varying the incubation time of reaction from 10 to $90 \mathrm{~min}$. Thermal stability of the purified enzymes (nitrile hydratase/amidase) was investigated at 25 to $55^{\circ} \mathrm{C}$.

\section{Effect of metals ion and other chemicals}

The nitrile hydratase and amidase activity was assayed in the presence of various metal ions and chemicals $\left(\mathrm{CaCl}_{2}\right.$, $\mathrm{CdCl}_{2}, \mathrm{CsCl}_{2}, \mathrm{CoCl}_{2}, \mathrm{CuSO}_{4}, \mathrm{FeSO}_{4}, \mathrm{HgCl}_{2}, \mathrm{MgSO}_{4}$, $\mathrm{MnCl}_{2}, \mathrm{ZnSO}_{4}, \mathrm{KCl}, \mathrm{NaCl}$, EDTA, DTT and urea) with a final concentration of $1 \mathrm{mM}$.

\section{Results and discussion}

\section{Purification}

Nitrile hydratase and amidase of Alcaligenes sp. MTCC 10674 were purified using different chromatography techniques. Acrylonitrile was used as substrate for nitrile hydratase characterization and propionamide was used as substrate for characterization of amidase. DEAE Sepharose ion exchange chromatography was performed and amidase got eluted with $0.125 \mathrm{M} \mathrm{NaCl}$ in fraction number 4-9 (Fig. 1) and further increase in $\mathrm{NaCl}$ concentration up to $0.15 \mathrm{M}$ resulted in nitrile hydratase elution (Fig. 2).
Fraction number $6,7,8,9,10$ and 11 of $0.15 \mathrm{M} \mathrm{NaCl}$ elution contained purified nitrile hydratase and 6.3-fold purification was achieved in a single step (Table 1). Nitrile hydratase has been already purified from various organisms Corynebacterium pseudodipthereticu and Rhodococcus rhodochrous PA-34 up to 8.8 and 52-fold, respectively ( $\mathrm{Li}$ et al. 1992; Prasad et al. 2009). Fraction 4, 5, 6, 7 and 8 obtained with $0.125 \mathrm{M} \mathrm{NaCl}$ showed amidase activity, were pooled together and applied in gel permeation column for further purification. Purified amidase was obtained in fraction number 14,15 and 16 (Fig. 3), and 9.2-fold purification was achieved (Table 2), previously amidase has been purified from Pseudonocordia thermophila and Delftia tsuruhatensis CCТССМ 205114 up to 48 and 105-fold, respectively (Egorova et al. 2004; Wang et al. 2011). The purified amidase consists of two subunits of 52 and $49 \mathrm{kDa}$ (Fig. 4a), while in native PAGE a single band of $114 \mathrm{kDa}$ was observed (Fig. 4b). Nitrile hydratase also exists as heterodimer of 24 and $21 \mathrm{kDa}$ (Fig. 5a), and in native PAGE a single band of $47 \mathrm{kDa}$ was observed (Fig. 5b). Purified amidase exists as dimer (52 and $49 \mathrm{kDa}$ ) and has two subunits $\alpha$ and $\beta$ as the amidase of Pseudonocardia thermophila $(2 * 52 \mathrm{kDa})$,

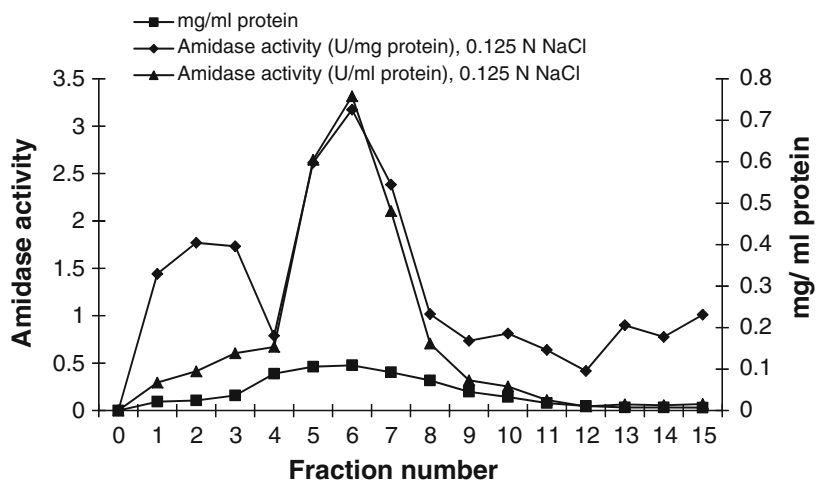

Fig. 1 Elution profile of protein and amidase activity with $0.125 \mathrm{~N}$ $\mathrm{NaCl}$ during DEAE-Sepharose chromatography

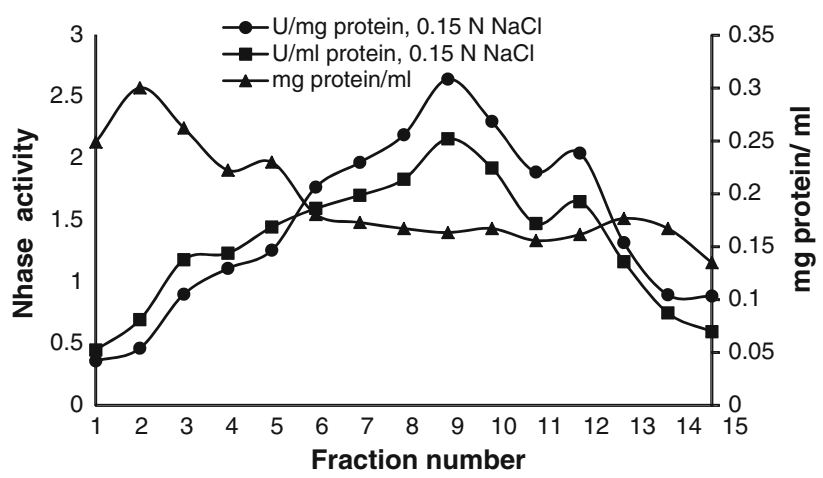

Fig. 2 Protein elution profile and Nhase activity profile in ion exchange chromatography with $0.15 \mathrm{~N} \mathrm{NaCl}$ elution 
Table 1 Purification summary of nitrile hydratase of Alcaligenes sp. MTCC 10674

\begin{tabular}{llllllll}
\hline Purification step & $\begin{array}{l}\text { Volume } \\
(\mathrm{ml})\end{array}$ & $\begin{array}{l}\text { Protein } \\
(\mathrm{mg} / \mathrm{ml})\end{array}$ & $\begin{array}{l}\text { Total } \\
\text { protein }(\mathrm{mg})\end{array}$ & $\begin{array}{l}\text { Total } \\
\text { activity }(\mathrm{U})\end{array}$ & $\begin{array}{l}\text { Specific activity } \\
(\mathrm{U} / \mathrm{mg})\end{array}$ & $\begin{array}{l}\% \text { Yield } \\
\text { Fold } \\
\text { purification }\end{array}$ \\
\hline Homogenate & 40 & 3.3 & 132 & 47.2 & 0.35 & 1 \\
20-60\% & 12 & 6 & 72 & 35.0 & 0.48 & 74 & 1.4 \\
DEAE-Sepharose & 8 & 0.163 & 1.304 & 2.904 & 2.22 & 6.3 \\
\hline
\end{tabular}

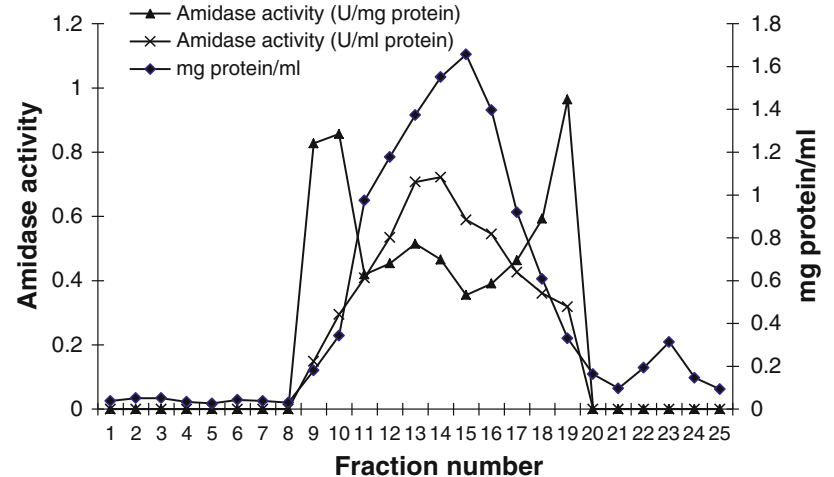

Fig. 3 Elution profile of protein and amidase activity during gel permeation chromatography

Brevibacterium sp. R312 (2*54.7 kDa) (Egorova et al. 2004; Baek et al. 2003). Nitrile hydratase was found as heterodimer of 24 and $21 \mathrm{kDa}$, as already reported in Rhodococcus sp. AJ270 ( $\alpha-22.9, \beta-23.4)$ and Rhodococcus equi TG328-2 ( $\alpha$-23, $\beta$-24) (Song et al. 2007; Rzeznicka et al. 2010).

Buffer $\mathrm{pH}$ and molarity dependence of Nhase and amidase

Nhase and amidase have maximum hydrolysis activity, i.e., $1.75 \mathrm{U} / \mathrm{mg}$ protein and $1.2 \mathrm{U} / \mathrm{mg}$ protein, respectively in sodium phosphate buffer ( $\mathrm{pH}$ 8.0). Nitrile hydratase requires $0.125 \mathrm{M}$ buffer for optimum activity $(0.14 \mathrm{U} / \mathrm{mg}$ protein) and maximum amidase activity was achieved in $0.075 \mathrm{M}(1.95 \mathrm{U} / \mathrm{mg}$ protein). Both the enzymes are active at neutral $\mathrm{pH}$, as already reported for the nitrile hydratase of Corynebacterium sp. C5 (Tani et al. 1989).
Effect of temperature

Amidase showed maximum activity at $45{ }^{\circ} \mathrm{C}(2.3 \mathrm{U} / \mathrm{mg}$ protein), while nitrile hydratase at $15{ }^{\circ} \mathrm{C}(2.4 \mathrm{U} / \mathrm{mg}$ protein). Deviation from the optimal temperature decreased the activity of both enzymes. Amidase has optimum activity at $45{ }^{\circ} \mathrm{C}$ same to the amidases of Pseudonocardia thermophila, Bravibacillus sp. R312, and Sulfolobus solfataricus, while hydratases require low temperature for its optimum activity as already reported in Brevibacterium $\mathrm{sp}$. R312, Rhodococcus sp. AJ270 and Rhodococcus equi TG328-2 (Egorova et al. 2004; Baek et al. 2003; Song et al. 2007; Rzeznicka et al. 2010; Kotlova et al. 1999; d'Abusco et al. 2001).

$K_{\mathrm{m}}$ and $V_{\max }$ value

Amidase has $V_{\max }$ of $12.5 \mu \mathrm{mol} / \mathrm{min} / \mathrm{mg}$ and $K_{\mathrm{m}}$ of $45.5 \mathrm{mM} . K_{\mathrm{m}}$ values using propionamide as substrate has been reported earlier from Pseudonocardia thermophila (7.4 mM), Rhodococcus sp. (1 mM), Rhodococcus erythropolis $(1.3 \mathrm{mM})$, Rhodococcus sp. (2.6 mM), Rhodococcus sp. N-771 (34.2 mM) and Brevibacterium sp. (88 mM), respectively, while $V_{\max }$ for Pseudomonas putida was 0.019 (Egorova et al. 2004; Fournand et al. 1998; Park and Uhm 2008; Nawaz et al. 1994; Thiery et al. 1986; Wyndham and Slater 1986). Purified nitrile hydratase has $K_{\mathrm{m}}$ and $V_{\max }$ value for acrylonitrile as $40 \mathrm{mM}$ and $10 \mu \mathrm{mol} / \mathrm{min} / \mathrm{mg}$, respectively. Nitrile hydratases of Brevibacterium sp. and Nocardia sp. (Kaakeh et al. 1991; Yu et al. 2006) have $K_{\mathrm{m}} 16.6,16.7$ and $82 \mathrm{mM}$, respectively, while $V_{\max }$ value for Rhodococcus sp. RHA1 and Rhodococcus $\mathrm{sp}$. SHZ1 were respectively 2.8 and $12.3 \mu \mathrm{mol} / \mathrm{min} /$ mg (Wang et al. 2007).

Table 2 Purification summary of amidase of Alcaligenes sp. MTCC 10674

\begin{tabular}{llllllll}
\hline Purification step & Volume & $\begin{array}{l}\text { Protein } \\
(\mathrm{mg} / \mathrm{ml})\end{array}$ & $\begin{array}{l}\text { Total } \\
\text { protein }(\mathrm{mg})\end{array}$ & $\begin{array}{l}\text { Total } \\
\text { activity }(\mathrm{U})\end{array}$ & $\begin{array}{l}\text { Specific activity } \\
\text { (U/mg protein) }\end{array}$ & $\begin{array}{l}\% \text { Yield } \\
\text { pold } \\
\text { purification }\end{array}$ \\
\hline Homogenate & 40 & 3.3 & 132 & 18 & 0.14 & 1.00 & 1.0 \\
20-60\% & 12 & 6 & 72 & 12 & 5.5 & 0.40 & 66 \\
DEAE-Sepharose & 10 & 1.4 & 14 & 3.36 & 1.30 & 30 & 1.1 \\
Sephacryl-100 & 6 & 0.44 & 2.64 & &
\end{tabular}


Fig. 4 a SDS-PAGE of purified fractions of amidase, lane (1) marker (2) and (3) purified fraction. b Native-PAGE analysis of purified amidase fraction, lane (1) Marker (2) crude (3) precipitate (4) pooled fraction of ion exchange chromatography (5) purified fraction of gel permeation (6) and (7) zymogram of purified fraction 6

Fig. 5 SDS-PAGE of nitrile hydratase, a lane (1) marker (2) crude (3) precipitate (4) fraction number 14,15 . b Native-PAGE analysis of purified nitrile hydratase (1) marker (2) crude (3) precipitate (4) purified fraction 14 and 15
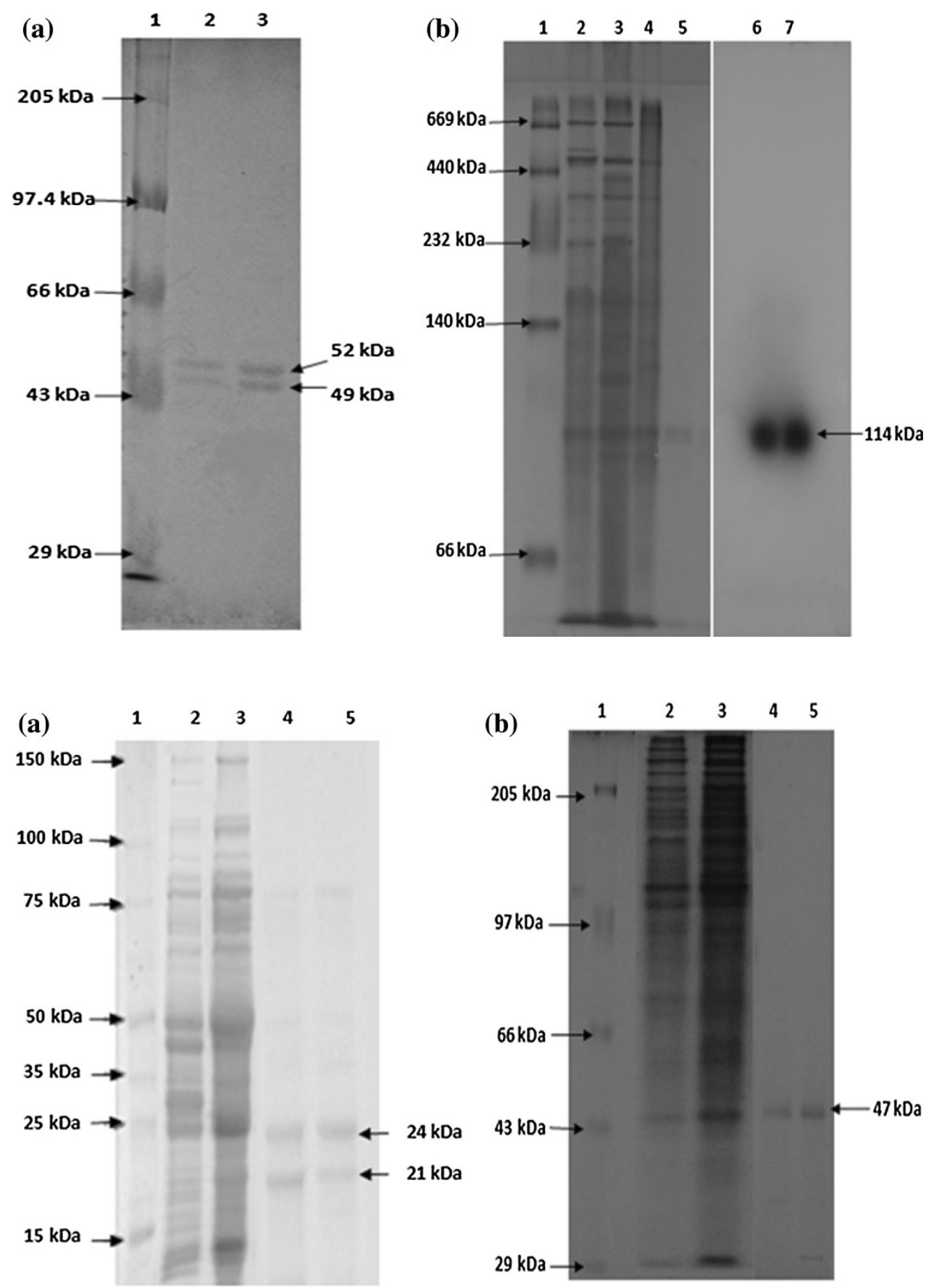

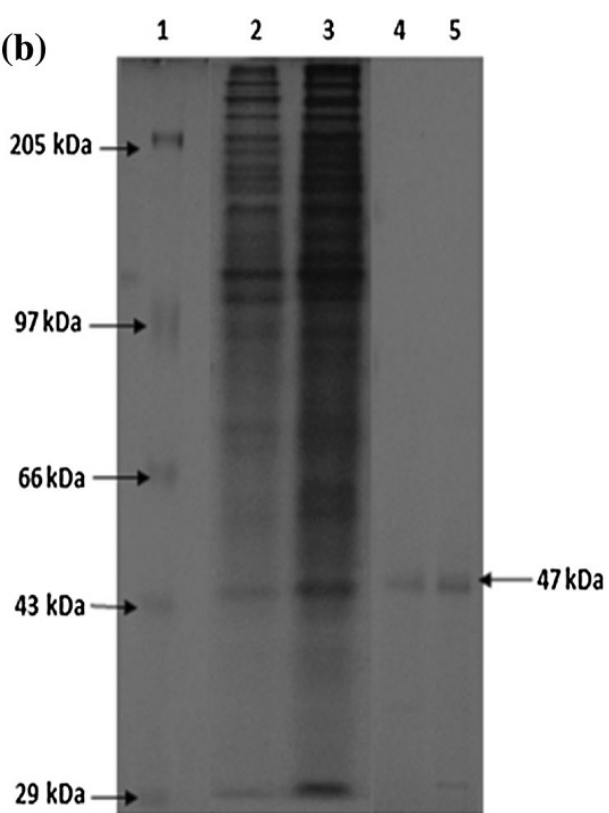

Incubation time and stability

Activities of nitrile/amide hydrolyzing enzymes were determined at different time interval (10-90 min). Nitrile hydratase and amidase gave maximum activity, respectively, 4.6 and $6.4 \mathrm{U} / \mathrm{mg}$ protein at $20 \mathrm{~min}$ of incubation. Amidase has half lives of $31 \mathrm{~h}, 23 \mathrm{~h}, 10 \mathrm{~h}, 4 \mathrm{~h}, 3 \mathrm{~h}$ and $2 \mathrm{~h}$ $30 \mathrm{~min}$, respectively at $10,15,25,35,45$ and $55^{\circ} \mathrm{C}$, while nitrile hydratase has half lives of $43,31,5,3,2.6$ and $1 \mathrm{~h}$, respectively at $10,15,25,35,45$ and $55^{\circ} \mathrm{C}$. Both enzymes were stable at lower temperature, and increase in temperature resulted in rapid inactivation of enzyme. Amidase has half lives of $2 \mathrm{~h} 30 \mathrm{~min}$ at $55^{\circ} \mathrm{C}$, while amidase of Rhodococcus erythropolis No. 7 has a half life of $30 \mathrm{~min}$ at $55^{\circ} \mathrm{C}$ (Park and Uhm 2008). Nitrile hydratase has half lives of $31 \mathrm{~h}$ at $15^{\circ} \mathrm{C}$ and is more stable in comparison to nitrile hydratase of Microbacterium imperiale CBS 498-74 having half life of $6.5 \mathrm{~h}$ (Cantarella et al. 2004). Both enzymes are stable at lower temperature, increase in temperature resulted in rapid inactivation of enzyme. 
Fig. 6 a Effect of metal ions on amidase activity. $\mathbf{b}$ Effect of metals ion on nitrile hydratase activity
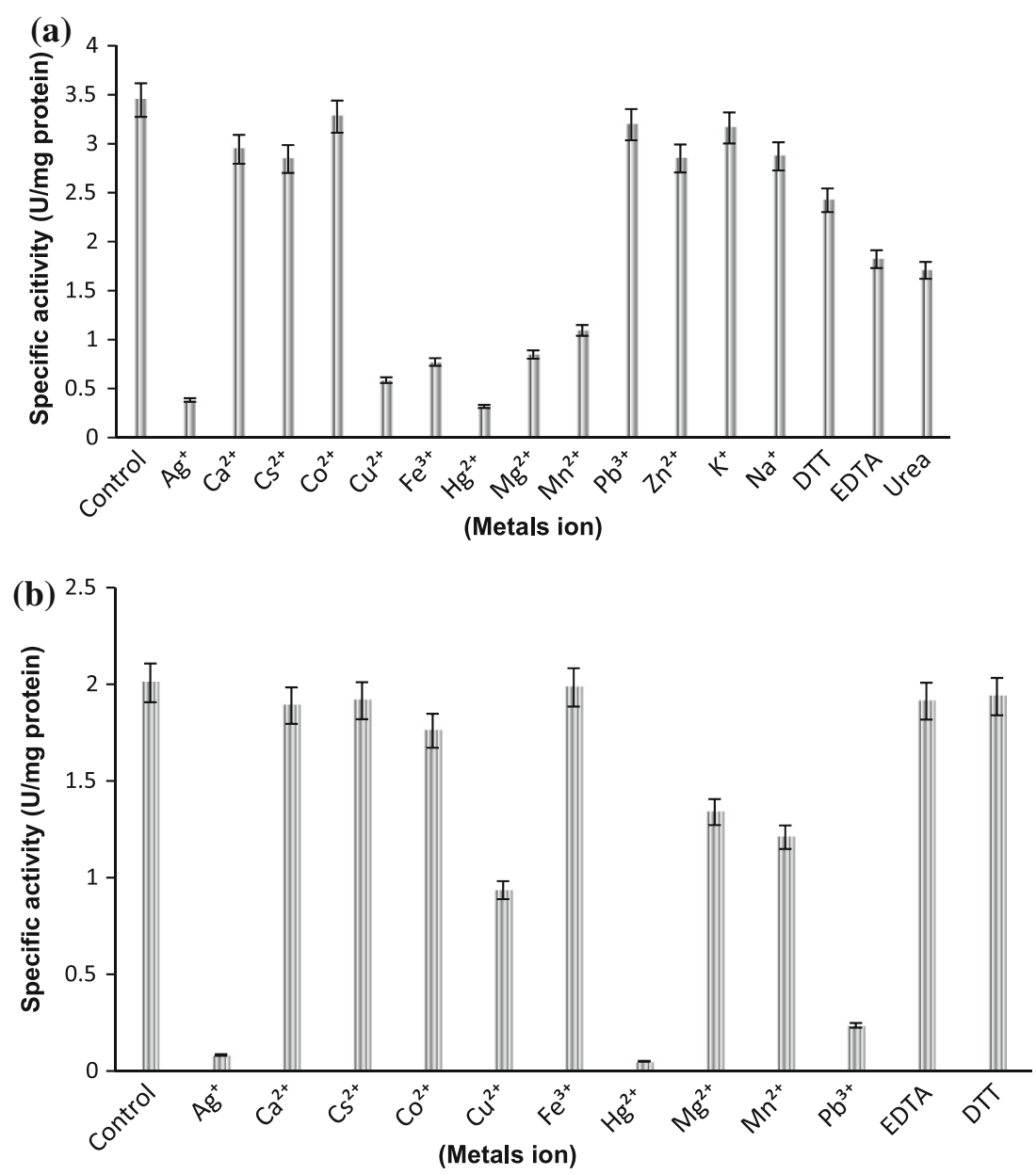

Effect of metal ions

Alcaligenes sp. MTCC 10674 nitrile/amide hydrolyzing enzymes were strongly inhibited by heavy metals ion. Addition of $\mathrm{Hg}^{2+}, \mathrm{Ag}^{+}, \mathrm{Pb}^{2+}, \mathrm{Cu}^{2+}, \mathrm{Fe}^{2+}$ and $\mathrm{Mg}^{2+}$ resulted into $92,89,88,83,77$ and $75 \%$ inhibition of amidase activity (Fig. 6a). In case of Nhase, addition of $\mathrm{Hg}^{2+}, \mathrm{Ag}^{+}, \mathrm{Pb}^{2+}$ and $\mathrm{Cu}^{2+}$ in reaction resulted into 97, 95,88 and $55 \%$ inhibition of activity, respectively (Fig. 6b). Other metal ions and chemical compounds, i.e., $\mathrm{Ca}^{2+}, \mathrm{Cs}^{2+}, \mathrm{Co}^{3+}, \mathrm{Zn}^{2+}, \mathrm{Na}^{+}, \mathrm{K}^{+}$, urea, EDTA and DTT showed no significant effect on nitrile hydratase and amidase activity. Alcaligenes sp. MTCC 10674 nitrile/amide hydrolyzing enzymes were strongly inhibited by heavy metal ions. Metal ions $\mathrm{Hg}^{2+}, \mathrm{Ag}^{+}, \mathrm{Pb}^{2+}$ and $\mathrm{Cu}^{2+}$ are strong inhibitors of nitrile hydrolyzing enzyme activity. Metal ions inhibition study revealed that enzymes contains sulfhydral $(-\mathrm{SH})$, alcohol, or acid groups as part of their active sites, any reagent/metal ion which can react with these side groups of amino acid and act as an irreversible inhibitor. Heavy metals such as $\mathrm{Ag}^{+}, \mathrm{Hg}^{2+}$ and $\mathrm{Pb}^{2+}$ have strong affinities for - $\mathrm{SH}$ groups and inhibit activity of nitrile metabolizing enzyme Paracoccus sp. M-1 (Shen et al. 2012). Several amidases and nitrile hydratase enzyme have been already purified, but simultaneous purification of these two enzymes, however, appear unique which makes this purification process simple and rapid.

Acknowledgments The authors acknowledge the Department of Biotechnology and University Grant Commission, India for financial support in the form of Senior Research Fellowship to Mr. Shashi Kant Bhatia, Praveen Kumar Mehta and Ravi Kant Bhatia. The computational facility availed at Bioinformatics Centre, H P University is also duly acknowledged.

Open Access This article is distributed under the terms of the Creative Commons Attribution License which permits any use, distribution, and reproduction in any medium, provided the original author(s) and the source are credited.

\section{References}

Baek DH, Song JJ, Lee SG, Kwon SJ, Asano Y, Sung MH (2003) New thermostable D-methionine amidase from Brevibacillus borstelensis BCS-1 and its application for D-phenylalanine production. Enzyme Microb Tech 32:131-139 
Bhalla TC, Kumar H (2005) Nocardia globerula NHB-2: a versatile nitrile-degrading organism. Can J Microbiol 51:705-708

Bhatia RK, Bhatia SK, Mehta PK, Bhalla TC (2012) Bench scale production of benzohydroxlic acid using acyl transferase activity from Alcaligenes sp. MTCC 10674. J Indus Microbiol Biotechnol. doi:10.1007/s10295-012-1206

Bhatia SK, Mehta PK, Bhatia RK, Bhalla TC (2013) An isobutyronitrile induced bienzymatic system of Alcaligenes sp. MTCC 10674 for the production of alpha-hydroxyisobutyric acid. Bioprocess Biosyst Eng 36(5):613-625

Bradford MM (1976) A rapid and sensitive method for the quantization of microgram quantities of protein utilizing the principle of protein-dye binding. Anal Biochem 72:248-254

Brady D, Beeton A, Zeevaart J, Kgaje C, Rantwijk FV (2004) Characterisation of nitrilase and nitrile hydratase biocatalytic systems. Appl Microbiol Biotechnol 64:76-85

Branner C (2002) Catalysis in the nitrilase superfamily. Curr Opin Stuct Biol 12:775-782

Cantarella M, Cantarella L, Gallifuoco A, Frezzini R, Spera A, Alfani F (2004) A study in UF-membrane reactor on activity and stability of nitrile hydratase from Microbacterium imperiale 498-74 resting cells for propionamide production. J Mol Catal B 29:105-113

d'Abusco SA, Ammendola S, Scandurra R, Politi L (2001) Molecular and biochemical characterization of the recombinant amidase from hyper thermophilic archaeon Sulfolobus solfataricus. Extremophiles 5:183-192

Egorova K, Trauthwein H, Verseck S, Antranikian G (2004) Purification and properties of an enantioselective and thermo active amidase from the thermophilic actinomycetes Pseudonocardia thermophila. Applied Microbiol Biotechnol 65:38-45

Fournand D, Arnaud A, Galzy P (1998) Acyl transfer activity of an amidase from Rhodococcus sp. strain R312: formation of a wide range of hydroxamic acids. J Mol Catal B 4:77-90

Kaakeh MR, Legras JL, Duran R, Chion ch KNCK, Arnaud A, Galzy P, Zentralbl (1991) Purification and properties of the nitrile hydratase of a new strain of Rhodococcus sp. Microbiol 146:89-98

Kotlova EK, Chestukhina CG, Astaurova OB, Leonova TE, Yanenko AS, Debaboy VG (1999) Isolation and primary characterization of an amidase from Rhodococcus rhodochrous. Biochemistry (Mosc) 64:384-390

Laemmli UK (1970) Cleavage of structural proteins during the assembly of the head of bacteriophage T4. Nature 227:680-685

Li WZ, Zhang YQ, Yang HF (1992) Formation and purification of nitrile hydratase from Corynebacterium pseudodiphteriticum ZBB-41. Appl Biochem Biotechnol 36:171-181

Nawaz MS, Khan AA, Seng JE, Leakey JE, Siitonen PH, Cerniglia CE (1994) Purification and characterization of an amidase from an acrylamide-degrading Rhodococcus sp. Appl Environ Microbiol 60:3343-3348

Park HJ, Uhm KN (2008) HKR-stereoselective amidase from Rhodococcus erythropolis No. 7 acting on 4-chloro-3-hydroxybutyramide. J Microbiol Biotechnol 18:552-559
Prasad S, Misra A, Jangir VP, Awasthi A, Raj J, Bhalla TC (2007) A propionitrile-induced nitrilase of Rhodococcus sp. NDB 1165 and its application in nicotinic acid synthesis. World J Microbiol Biotechnol 23:345-353

Prasad S, Raj J, Bhalla TC (2009) Purification of a hyperactive nitrile hydratase from resting cells of Rhodococcus rhodochrous PA34. Indian J Microbiol 49(3):237-242

Raj J, Prasad S, Bhalla TC (2006) Rhodococcus rhodochrous PA-34: a potential biocatalyst for acrylamide synthesis. Process Biochem 41:1359-1363

Rzeznicka K, Schatzle S, Bottcher D, Klein J, Bornscheuer UT (2010) Applied Cloning and functional expression of a nitrile hydratase (NHase) from Rhodococcus equi TG328-2 in Escherichia coli, its purification and biochemical characterization. Appl Microbiol Biotechnol 85:1417-1425

Sharma M, Sharma NN, Bhalla TC (2012) Biotransformation of acetamide to acetohydroxamic acid at bench scale using acyl transferase activity of amidase of Geobacillus pallidus BTP-5x MTCC 9225. Indian J Microbiol 52(1):76-82

Shen W, Chen H, Kaizhi J, Jun N, Yan X, Li S (2012) Cloning and characterization of a novel amidase from Paracoccus sp. M-1, showing aryl acylamidase and acyl transferase activities. Appl Microbiol Biotechnol 4:1007-1013

Singh R, Sharma R, Tiwari N, Geetanjali Rawart DS (2006) Nitrilase and its application as a 'green' catalyst. Chem Biodivers 3: 1279-1287

Song L, Wang M, Yang X, Qian S (2007) Purification and characterization of the enantioselective nitrile hydratase from Rhodococcus sp. AJ270. Biotechnol J 2:717-724

Sorokin DY, Pelt S, Tourova TP, Takaichi S, Muyzer G (2007) Acetonitrile degradation under haloalkaline conditions by $\mathrm{Na}$ tronocella acetinitrilica gen. nov. sp. nov. Microbiol 153: $1157-1164$

Tani Y, Kurihara M, Nishise H (1989) Characterization of nitrile hydratase and amidase, which are responsible for the conversion of dinitriles to mononitriles, from Corynebacterium sp. Agric Biol Chem 53:3151-3158

Thiery A, Maestracci M, Arnaud A, Galzy P (1986) Acyltransferase activity of the wide spectrum amidase of Brevibacterium sp. R312. J Gen Microbiol 132:2205-2208

Wang C, Zhang G, Xu X, Li C (2007) Inducing expression and reaction characteristic of nitrile hydratase from Rhodococcus sp. SHZ-1. Chin J Chem Engin 15:573-578

Wang YS, Cheng F, Zheng RC, Wang YJ, Zheng YG (2011) Characterization of an enantioselective amidase with potential application to asymmetric hydrolysis of ( $\mathrm{R}, \mathrm{S})$-2, 2-dimethylcyclopropane carboxamide. World J Microbiol Biotechnol 27:2885-2892

Wyndham RC, Slater JH (1986) A comparative study of acquired amidase activity in Pseudomaonas sp. J General Microbiol 132:2185-2204

Yu H, Shi Y, Luo H, Tian Z, Zhu Y, Shen Z (2006) An over expression and high efficient mutation system of a cobaltcontaining nitrile hydratase. J Mol Catal B 43:80-85 